\title{
SOME USEFUL APPROACHES ON TEACHING LISTENING IN TECHNICAL EDUCATIONAL ESTABLISHMENTS
}

\author{
Otabek A. Mavlonov \\ Turin Polytechnic University in Tashkent
}

\section{Annotation}

The article elucidates some theoretical basis and main problems relating to the process of teaching listening for technical students. The author tried to analyze sufficiently the professional-oriented training, new and traditional methods of teaching listening presented by various authors and specialists. Besides, it has also been given some proposal improving listening skills by using modern information technologies and in some insufficient situations as well.

Key words: modern and traditional approaches, listening, self-study, professional-oriented, communicative learning, audio text, perception, monitoring, strategy, teaching, training, data, facts

The importance of foreign languages in the modern world is difficult to exaggerate, if only because the 21 st century is called by many officials the 'century of polyglots,' that the owning of a foreign language, or even a few, becomes a necessary condition for education in a postindustrial society. With the increasing integration of the world community and the inclusion of our country in the world economic system, a foreign language is considered as a means of communication in future professional activities. From the position of a modern competence approach, the strategic goal of teaching foreign languages at higher education institutions is the formation of a 'secondary linguistic personality' of a specialist, ready for professional intercultural communication. Therefore, the most important requirement for the level and quality of specialist training is its level of linguistic training.

Now there are prerequisites for revising the existing approach to training and the methods used and updating them on the basis of modern approaches that meet the requirements of modernizing vocational education, the social order of society and the latest achievements in the field of methodology and related sciences. Many researchers of the problems of teaching foreign languages in higher education assign them to some modern directions in education: a profound understanding of educational levels as a continuous chain of education; computerization and technologization of education, contributing to the development of students' intellectual activity; the introduction of active methods and forms of education, including in the activities of students the elements of problematic, scientific research, independent work [2:73]; the use of active teaching methods that stimulate and organize communication, creative and independent activity of students; focus on the organization of training as a collective, joint activity of the teacher and student, which involves the use of interactive learning methods.

According to some specialists above mentioned directions indicate that the activity orientation of language education at the university remains the most 
significant. This does not contradict the competence approach that is currently being developed, which is intended to replace the system of knowledge and skills with a set of competencies that will be formed among students on the basis of updated content and in the process of their activity in mastering this content [5:32].

Listening foreign language is one of the hardest aspect of the speech activities to master, as listening is an active intellectual speech process, during which there is the hard work of all mental and intellectual mechanisms for the perception of sounding speech, perception obtained in the audio form of information, its recognition, interpretation and understanding of the meaning. Under the conditions of a technical college or university the problem of training to audition of foreign language, especially English-speaking, professionally-oriented text content is particularly acute. On the one hand, the state educational standard of higher education in all directions require the formation of foreign language communicative competence of university graduates, which should 'be able to use a foreign language in professional work, professional communication and interpersonal communication' which implies formation of professional content of the texts on the listening perception skills. On the other hand, the practice of education shows that a professionally-oriented listening is still the least developed area in the foreign language teaching methodology in non-language universities due to the insufficient number of classroom hours, the lack of teaching aids and development of listening specialized texts, as well as the lack of experimental is a statistical data on the effectiveness of the used procedures.

Representatives of Engineering, Information Technologies and Mechanics cannot deny the importance of the activities of foreign languages. Many foreign languages, especially English language is taught thoroughly in institutions of higher education, colleges and academic lyceums according to the various documents which have been adopted by the government in order to improve the teaching of foreign languages. Although the foundation of studying the language is primarily laid in preschool education institutions, secondary schools, the main knowledge in learning languages is gained at high schools, colleges or at universities. Because, educational institutions listed above, the main emphasis is paid to the general aspects of the language, many institutes and universities in special cases that are taught according to the directions. Advantages of the method are that, depending on foreign language teaching can be summarized with a few more factors than others.

Despite the fact that in recent times there are interesting works on this topic, the effective organization of training to audition for professional purposes has not lost its importance and relevance. Successful listening skills are acquired over time and with lots of practice. Your students need exposure to spoken English to be able to develop their listening skills. However, students in some parts of our country may not have many opportunities to listen to English outside the classroom. Nevertheless, Listening, as an integral part of the communicative learning process, faces a great number of challenges [1:90]. This article includes some approaches and experience of training to audition of professional English texts of a technical college and university students. 
The essence of the professional-oriented training of audition is to form skills of perception and understanding of the statements of the interlocutor in a foreign language, generated in monologue form, or in the process of dialogue in accordance with a certain area of a real professional situation and working. In this case listening can also act as an educational goal (perception and interpretation of the English listening comprehension with subsequent analysis of the information obtained and using it), and as a means of training or self-study (audio and video materials used by students as a source of information for the preparation of creative tasks) and as a means of monitoring and self-knowledge learned lexical and grammatical material in the final stages of working with it.

The functional component of listening as an end in itself in technical colleges or universities includes possession of different types of listening, in accordance with the content of audio materials that have a strong scientific and professional orientation. Students of technical universities are very sensitive to the content of texts advocating the obvious motivating learning factor. In their view, the text must be professionally saturated, including modern and consistent information (facts, data), focused on the latest advances in science and technology, directly reflect their professional interests, providing an opportunity to learn something new. The level of English proficiency, as a whole, and the level of formation of skills of listening, in particular, does not matter.

From the methodological point of view, selection criteria of audio materials are, firstly, the monitoring of knowledge level (language and vocational) students of a particular group, and secondly, genre and stylistic and functional-pragmatic features of the texts themselves.

In practice, the selection of the content of training to audition audio materials is carried out in the following sequence: testing is conducted primary language skills of students and their academic and professional interests; being fixed the amount of the ultimate knowledge that a student must possess; selection is made, and minimization of the actual metering (grammatical, lexical, substantive) material covering the scope of the target communication; chosen strategy of training and appropriate training tasks in communicative orientation; eliminating the difficulties of perception of each text, which can be caused by high-speed voice, unfamiliar rhythmic structures, a large number of speakers, emotionally speaking, background noise, etc.

Content of audio texts must meet the following criteria: the authenticity of the sources; professional orientation of information: reflection of spheres of activity, professional communication situations professionally important subjects; functional, stylistic and genre correlation with the acquired specialty; samples submitted monologue and dialogue speech; the existence of socio-cultural and regional geographic data subjects; relevant to the level of professional and language training of students: the appropriate level of difficulty of lexical and grammatical content of the text; some sound pace, distinctness of pronunciations; including in the audio noisy background; Phonetic painting (see detail about the features audio texts [6:219-240].) 
Within the scope of a professionally-oriented training selection of audio materials must correspond to the genre and functional-stylistic features of the professional spheres. Based on this criterion, audio materials must reflect the genres of scientific style as reports, lectures, scientific discussion, debate, presentation of projects and industrial and technical style of speech - instruction, message, description of the production process / technical devices / technologies. As forms of oral speech audio materials are monologue and dialogue expressions. Monologue (lecture, audio track of scientific, popular scientific works, information broadcasts, video documentaries and television programs, audio and video materials that are freely available on the Internet, including various professional sites or YouTube), the most popular forms audio texts in academic and professional plans. Successful audition of monologue statements depend on the background of conceptual knowledge on the subject; the ability to differentiate between essential and non-essential; the ability of listeners (students) to focus for a long time, know the lexical and grammatical and stylistic features of oral lectures (ellipses, hesitations, repetitions, concretions, academic professionalism, jargon, etc.); understanding in terms of large and complex content segments sounding speech. Teaching audition of dialogical speech takes place in two directions: the student can either be an active participant in the conversation, when audition serves as a component of oral and verbal communication during an activity, or indirectly, while talking on the phone or talking with the use of modern communication means, such as Skype, whose members serve in rotation, the role of the speaker, the role of the listener, or a passive listener, without having the opportunity to influence the course of the conversation, or ask again to clarify some details (listening to the dialogue).

In the development of learning strategies in teaching listening abovementioned audio texts must also take into account the kind of audition and mental processes of perception / interpretation of the information involved in its implementation. It should be noted that any work on audio texts includes some stages like motivational and incentive (installation, motive and purpose), analytical and synthetic (perception and processing of text), Executive (understanding) [7:225].

Each stage has its own set of tasks: pre-listening, while listening and post listening activities. But nowadays these tasks are not novelty in teaching foreign languages and familiar for most teachers of various languages.

During motivational incentive stage orientation takes place, attitude of students to type the text that they have to hear, and the information that they need to be learned from listening experience. At this stage, students are instructed what text they listen (to the interview ...; lecture about ..., dialogue ...); necessary background information about the text; listen to give a reduced, simplified or slow recording option to listen to the full text; mark out and read along with the teacher keywords and phrases that appear in the text; offer to study photos, diagrams, drawings; provide an opportunity to read the summary.

In perception and text revision phase students collate what they heard that have previously known. Their background knowledge becomes a support for 
understanding sounding text. Thus, this stage is inextricably linked to the stage of understanding of the text. The level of understanding impacts on the performance of tasks after the text. Tasks performed in the process of listening, can be divided into the following types: questions: a) the choice of questions; b) true / false / not given; c) questions that have no definite answer; Recognition: a) identify the type of text (advertising, interviews, comment, story, etc.); b) define the context: who is talking to whom, about what, when, etc .; c) Recognize the selected unit, that is, the keywords, the amount of use of a particular expression, all the names, for example, the technical unit (terms), etc .; correlation: a) Match the description with the corresponding pictures, diagrams, b) Relate a sequence of events in the text, the order of operation of the technical device; execution of instructions: a) Complete the chart / diagram / table / drawing; b) fill in the chart / diagram; c) mark the objects in the picture; d) note the order of the work; d) Draw a diagram, etc .; notes: a) fill; b) fill in the schedule sequence of operations, such as assembly of anything; c) make notes on key words on the topic; Interpretation: a) listen to comments in the dialogue (or interview) and assessed the relationship of the speaker, for example, approval / disapproval; the use of decryption: a) mark a pause in decoding storytelling that has no punctuation; b) Listen to the text and check the small differences that occur in deciphering the text; End: a) fill in the blanks with the missing words; b) complete the sentence unsaid; c) 'Role Listening': dialogue listen pairs, each student plays the role of one of the speakers, followed by playing the role of oral discussion; d) completion of the dialogue or communication: learners listen to only one of the speakers.

For instance, students are suggested to watch and listen to a video about the features of space engines, before that they are encouraged to read the small text of the same theme. Then the text comes back the teacher and the students are given the task to choose the appropriate information. They can do this in the process of listening to as well as after it, which helps students focus and better perception and interpretation of the audio information.

At the stage of understanding the tasks should involve students in creative activities. It offers the following activities: ask for the name of the text; make up questions and answers based on the interpretation of what was said; The title or role-play what might have happened before or after the listened text; express your opinion on a particular subject; describing the character and personality of participants in the dialogue; discuss the article's author position of the interviewee, reporter and others. The chain of different types of learning activities leads to speaking after listening. Audio materials set the basic framework and provide the material for the further development of English communicative competence.

Experience of usage of audio and video from internet sites indicates their effectiveness in the process of training to audition in the student audience of a technical college. Students try to remember the English interpretation of the wellknown physical phenomenon or theoretical material, making records of individual words and phrases, and then in the group recreate the entire text.

There are several kinds of listening: educational; communicative; with a full understanding of the content of the text; extraction with selective information; a 
critical assessment. Each type is oriented to the formation, development, testing and the use of listening skills, aided by a set of exercises designed[7:239].

Academic listening serves as a learning tool or a method of introducing a new language material, it is a prerequisite for the formation of oral communication skills, the formation and improvement of the communication skills of listening.

Working in the computer class or at home allows you to work more thematically related to the texts and their subsequent discussion and implementation of the various creative tasks. Students have the opportunity to repeatedly listen to the lyrics and translations to train. The use of these texts in the record format in the classroom allows you to quickly and effectively demonstrate the new language material, with its high-quality primary practicing. It should be noted that repeated listening during class work under the guidance of a teacher or extracurricular self-study allows for a better understanding of the audio material, practicing of pronunciation skills of individual language units, remembering the lexical and grammatical structures typical for professional texts, and further interpretation of its content.

In conclusion, we can say that the teaching professional-focused listening in technical colleges and universities play an important role in the training of highly qualified specialists who are able to actively participate in a variety of situations of international cooperation. Ability in listening and understanding the English language professional orientation is a key point in communication of professionals. This can and must be learned in the framework of higher educational program under the guidance of a teacher, and in the process of self-study.

\section{BIBLIOGRAPHY:}

1. Chebotarova I. G., Shcherban L. M.. The Importance of Listening in Teaching Foreign Languages at Technical Universities./ Вісник 6/ 2015

2. Efremova N.Oksana, Plotnikova V. Inna, Anna K. Ustyuzhanina. Forming Linguistic Competence of Foreign Students at the Preparatory Department of a Technical University. Procedia - Social and Behavioral Sciences. Volume 215. 2015. Pages $72-78$

3. Gal'skova, N. D. Teoriya obucheniya inostrannym yazykam. Lingvodidaktika i metodika / N. D. Gal'skova, N. I. Gez. - M.: Akademiya, 2006.

4. Jacques, Ch. Technical English 3. Workbook /Ch. Jacques. - UK : Pearson Education Ltd, 2011.

5. Pchelintseva I.G.. Implementing of competence approach in the process of foreign language teaching in technical university. Bulletin of SibADI, Issue (1) 15, 2010. Pages 31-35.

6. Richards, J. Listening Comprehension: Approach, Design, Procedure / J. Richards // TESOL Quarterly. - 1983. - Vol. 17.

7. Shatilov, S. F. Metodika obucheniya nemetskomu yazyku v sredney shkole / M.: Prosveshcheniye, 1986.

8. Solovova, Ye. N. Metodika obucheniya inostrannym yazykam / - M.: Prosveshcheniye, 2004. 